\title{
Chapter 9. We Are Children Of The Land: A Keo Perspective
}

\section{Philipus Tule}

\section{Introduction}

This paper explores traditional forms of land tenure in the Worowatu subdistrict of the Keo region in Central Flores, Indonesia. The focus is on the communal attachment of community members, Muslims and non-Muslims, indigenous people and newcomers, to their inherited clan land (tana ko'o 'ine 'embu). ${ }^{1}$ The organisation of land tenure is tied to a number of traditional offices, reaching down from the 'Lord of the Land' ('ine tana 'ame watu) and the 'Overseers of the Land' ('ine ku 'ame lema) to the 'individual cultivators' (nio tiko éu tako).

Keo people believe that individuals do not own the land, rather the land owns them, in the same sense as a mother can be said to own her children. This philosophy is reflected in a number of traditional expressions. 'Mother land, father stone' ('ine tana 'ame watu) is the title for a Lord of the Land, and 'mother plain, father field' ('ine ku 'ame lema) is how the lower ranking Overseers of the Land are referred to. This sense of being children of the land leads Keo people to regard land certificates issued by the Government for any clan land as invalid and as not binding in any way.

Every individual community member can gain access to ancestral land by observing various rituals and social-political obligations. Incorporated members within a clan, such as war migrants (tama dia kono ondo) and invited warriors (kéu mére kambe déwa), are also given land to cultivate and settle on (tau koe nua kadi 'oda) on the proviso of observing a particular, local charter of propriety (adat). If migrants violate this adat charter, their land rights can be cancelled.

The paper will also explore land disputes. Disputes over land rights frequently require resolution, and may concern such issues as the extension of land boundaries ( $p$ i singi rete ra'i) or the right to claim the office of Lord of the Land. The people of 'Udi and Worowatu, for instance, once struggled to prevent the usurpation of their authority over the land by the neighbouring villages of Witu and Giriwawo. They had to fight, since they believed that if they were to lose their authority over the land to which they properly belonged as the Lord of the Land, they would lose their sense of identity and their rights to speak out.

The Keo region is located in the south of Central Flores, an island in the Nusa Tenggara Timur (NTT) Provinces of Indonesia (see Map 1). As a distinct ethnic or cultural group in the context of Central Flores ethnography, the name Keo 
still retains currency on Flores largely by virtue of its former recognition as a separate administrative sub-unit (Onderafdeeling NageKeo) within the system of Dutch colonial government, even though NageKeo was later merged with the Nage region (Forth 1994a: 95). ${ }^{2}$ In the modern administrative structure of the Indonesian State, Keo society incorporates Mauponggo, Keo Tengah and Nangaroro, three subdistricts (kecamatan) within the district (kabupaten) of Ngada with a total population of 46,313 people and a territory of some 300 square kilometres (BPS, Ngada 1995: 131).

\section{Map 1: The Keo Region of Central Flores}

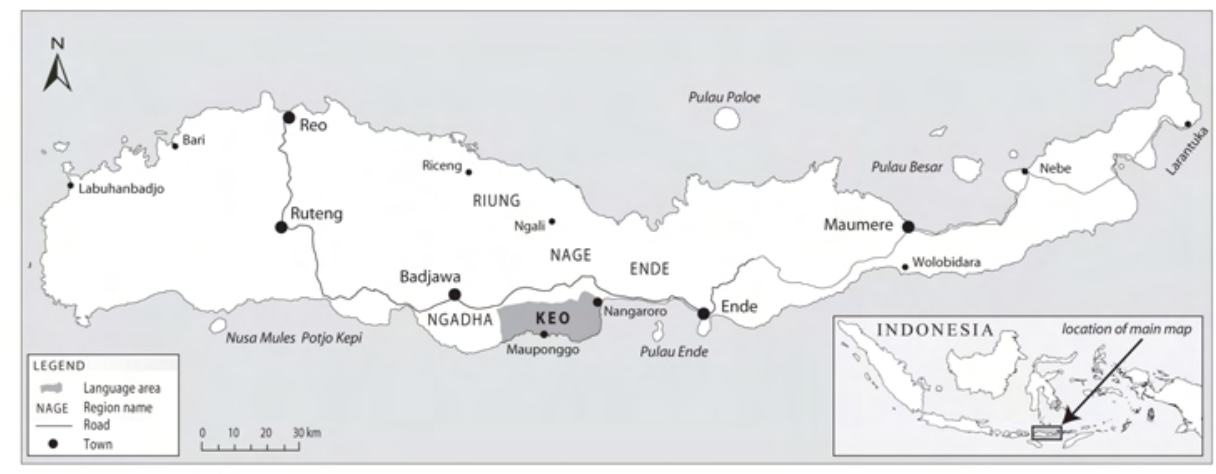

Source: Antropologi Indonesia, 56 (XXII): 70

While Keo is identical to its neighbour Nage in many details of culture, language and society, these two regions do display a number of general differences as compared with the neighbouring regions of Ngada and Ende. In terms of religion, nearly 93 per cent of the Keo are Catholics, and the remainder are Muslim fishermen and traders who live along the south coast between Maumbawa and Nangaroro. Catholicism was introduced to Keo in the 1920s, when Fr. Y. Ettel (SVD) started to visit several government schools and baptise students in Tonggo, Wajo and Sawu (Muskens, 1974: 1171). Most of the Catholic Keo nese are subsistence farmers and stock raisers. Today only a few Keo people practice their earlier, local religion in its entirety, but many do retain some elements thereof in their beliefs and ritual practices.

\section{The History and Development of Tana Worowatu}

The 'secondary district' (kepala mére) or 'domain' (tana) of Worowatu is named after the village (nua) of Worowatu (from, woro 'hill'; watu, 'stone'). According to a local myth, people established this settlement after a tsunami and inundation forced them to take refuge on the south slope of Mt Koto. This flood is blamed on the cancellation of a marriage between a Keo girl from Wondo village and a whale. Before the flood, the founding ancestor of Worowatu, a man called Taku Nuru, had resided at Tudiwado and had married the mythical girl 'Embu Tonga 
from the So'a region. When Worowatu was established as a secondary district (kepala mére) by the Dutch in 1917, the man appointed by the Dutch as subdistrict head (kepala mére) was Séme Rau, a direct descendant of Taku Nuru. ${ }^{3}$

It is interesting to note that the villages within Tana Worowatu are named on the basis of distinguishing features including natural or strategic features of their location. Worowatu village is named as such because it is located on a stony hill. Tudiwado (tudi, 'drop in or stop over';wado, 'return') refers to the strategic location of this settlement and the legendary hospitality of its people to travellers passing through. The name of the village, 'Udi, means 'rudder'. Kodinggi (kodi, 'lontar palm';engge, 'clusters') refers to the plenitude of lontar palms in this particular village. Its previous name, Bedo, which referred to an area the southern end of 'Udi village, might derive from a word belo, which means 'to make a turn' as the result of a rudder's function. Tonga Tonggo (tonga, 'to watch, supervise'; tonggo, 'the people from Tonggo') indicates a strategic position in which the people of Tonggo guard and supervise the coming of the people to an open market in Ma'undai. Ma'undai ( $m a^{\prime} u$, 'coast'; Ndai, name of a tribe) means the strip of coastline belonging to the Ndai people.

\section{Land Tenure in Worowatu}

Land tenure in contemporary Keo and in adjacent domains within the district of Ngada shows considerable variation, and there have also been a number of historical changes. Moreover, my study of the origin myths of 'Udi-Worowatu in conjunction with local oral history has convinced me that the region's land tenure system was never fixed and stable, but has been open to contestation from the beginning. Perhaps the most well-remembered case within living memory that demonstrates this openness is a dramatic conflict between the Worowatu and Witu-Ma'uara villages that occurred in 1937, and is known as léto laka witu. ${ }^{4}$

One of the more important historical changes came at the end of the 1950s, when the Indonesian Government introduced a new notion of the 'village' (desa) as an administrative unit within the structure of the State, or what locals refer to as 'new-style villages' (desa gaya baru). Until Indonesian independence, and for some time thereafter, the Keo men recognised and employed by the Dutch Colonial Administration to serve as local political leaders had invariably been their traditional leaders or 'lords of the land' ('ine tana 'ame watu).

The size of different communities' overall landholdings, and the amount of land accessible to individuals, has always varied greatly from one nua to another. My informants in 'Udi-Worowatu insisted that in other places a certain area of land, perhaps 10 hectares or more, was the informal minimum holding required if a person wanted to be a village leader (Kepala Mere orKepala Gemeente) under the Dutch. Control over extensive landholdings as such, however, was insufficient 
grounds to make someone a 'Lord of the Land' in 'Udi-Worowatu. Locals believe that this office is inherited from a powerful, named founding ancestor.

Taku Nuru was the founding ancestor of Worowatu, and his male-line descendants hold the right to the office of Lord of the Land over the area that includes Worowatu as well as 'Udi, Bedo, Witu and Ma'uara. This claim is supported by an oral history of origin:

The girl Tonga Mbu'e So'a was found as an infant by 'Embu Nderu in So'a, lying on a liana tree (tadi kada). 'Embu Nderu took the girl home and brought her up. When Tonga grew up into a beautiful young lady, she suggested to her adoptive mother, 'Embu Nderu. that they should go to the coast. 'Embu Nderu and Tonga Mbue Soa then moved down to the south coast of Flores through Ma'umbawa. They arrived at Seko Nangge, near 'Ae Tolo and Ma'umbawa. They stayed at the home of 'Embu Paja Wae. Tonga then left for Ma' undai to search for a tree without leaves (do kaju wunu mona). She met Taku Nuru, a local leader from Worowatu under the tree. They married. From that marriage, Tonga Mbue Soa gave birth to Waja 'Ake, Waja De'e and Waja Sébho, who were the grand ancestors of the people in Worowatu and Ma'undai.

The story further claims that from the beginning the Lord of the Land for the whole territory of Worowatu, including the villages Witu and Ma'uara, was always a descendant of Taku Nuru. His descendants claim that he is their founding ancestor. However, another group claims that Taku Nuru came from Koto Mountain and settled in Tudi Wado village before the others arrived. His wife, 'Embu Tonga Mbu'e So'a, is said to have been sent from afar, from outside, from a place called So'a near the town of Bajawa. She met Taku Nuru under 'a tree without a name and without leaves' (do kaju ngara mona ne'e wunu mona) in Ma' undai. ${ }^{5}$ An informant, Jamaludin Husein, a man from Ma'undai, even called them the Adam and Eve of Worowatu.

So'a, as the place of origin of 'Embu Tonga, seems to be referred to in myth but is not linked to any contemporary practices. For example, there is no evidence today to suggest a relationship between the two places (So'a and Worowatu) that may be framed as a wife-giving group ('embu mame) and wife-taking group ('ana weta) relationship. So'a, the home of the progenitor mother of the Worowatu people, is used here as a common place of origin. This seems to fit with a common idea among the Ngadha, that So'a (and Naru) are primeval places where earth and sky used to be connected with a liana tree. Gregory Forth also mentions that throughout the Nage and Keo regions one continually encounters the idea that the present population originally came from So'a, as did important items and traditions such as the areca palm and the practice of palm tapping(Forth 1998: 235-6). 
A second issue that would seem relevant to land tenure relates to the question of individual access to agricultural land. With remarkable unanimity of opinion, however, the people of Worowatu and Witu-Ma'uara proclaimed to me that they had few problems with regulating individual access to land. The real problem in contemporary Keo is how to maintain the idea that Worowatu and Witu-Ma'uara share the same land and belong to the same ritual confederacy, given that the creation of new style villages (desa gaya baru) such as 'Udi Worowatu and Witu Romba 'Ua has introduced a new pattern of territorial division and authority and is producing a widening gap between the two traditional groups. The new pattern of land tenure and land cultivation introduced under the administration of the two desa gaya baru seems to be creating a separation of Witu and Ma'uara from Worowatu. The modern administration has also challenged the office of Lord of the Land (who is from Worowatu), prompting a serious decline in his political and ritual authority. ${ }^{6}$ Before discussing these more recent conflicts, I will first describe traditional perceptions of land among the Keo in more detail.

\section{The Land is Our Mother}

In 'Udi-Worowatu, the land is considered the mother of the people. This is evident in ritual language discourse about death and in the honorific titles ofadat leaders. In metaphoric ritual language, those who have died are said to have 'returned to the mother's womb' (ta négha tama tuka 'ine) or to be 'under the soil and the stone' (ta négha wena tana 'au watu). ${ }^{7}$ Some informants elaborated further by adding the titles mother ('ine) to the land, and father ('ame) to the stone. The complete ritual speech couplet thus runs as follows: ta négha wena 'ine tana, ta négha 'au 'ame watu, 'those who are under mother soil and father stone'. The Keo believe that while the physical body may be destroyed, the soul (mae) continues to live, staying forever in the womb of its mother land. Such a belief leads people to make various kinds of offerings (wésa léla) to the ancestral spirits who dwell in their land.

The feeling of awe and respect for the land, as their parent and as a living body, takes shape as a sacred geography. For the 'Udi-Worowatu people, this geography is not limited and extends into the territory of their neighbours, because they tend to represent themselves as being at the centre of a wider universe:

\section{Tana mére Ende}

2. Watu déwa Jawa

3. 'Udu mbe'i kédi

4. A'i ndeli mesi
The great land extends to Ende. The long stone extends to Java. The head leans to the mountain (Koto).

The feet reach to the sea (Sawu). 
5. Puru wundu mbudu wutu

6. Négha mona dhu

7. Tana ha bhabha

8. Watu ha di'e

9. Dange wai toko pale

10. Bhondho wai toko odo
Stretching the fishing snare $40 \times 40$ arm lengths. ${ }^{a}$

Cannot reach far enough.

(Our) land is one piece.

(Our) stone is one unit.

The boundary is marked by clumps of rice.

The boundary is marked by clumps of sorghum.

a Wundu is a local variety of fishing line made from hand-spun cotton. Puru wundu mbudu wutu negha mona dhu means to extend 40 times 40 arm-lengths of cotton fishing line into the deep sea; and still it cannot reach the furthest reach of the border of their marine territory.

Worowatu ritual leaders tend to extend the idea of a sacred unity of the land to the domains of related neighbours, in Jawawawo, Wuji and Giriwawo villages to the north, on the slope of Mt Koto. At the same time, the southern boundary reaches into the Sawu Sea, to a distance greater than 40 rolls of traditional fishing snare (wundu).

My experience working with the locals and the ritual leaders on opening up the inter-village road from Ma'undai to Giriwawo in 1997, further illustrates the significance of this sacred geography. Locals argued that the new road should not run through the centre of their villages ( $n$ ua) because each village, with its various cultural monuments and functioning as a ritual site, is a sacred site. Even an abandoned village (nua 'odo), such as Nua Ora, is sacred because there people still find the ritual sites of founding ancestors such as Rangga 'Ame 'Ari. Another sacred site outside the village of Worowatu, which is called Watu Dia Meo (Stone of the Cat's Cave), is also protected from violation. People also say that the blood of the ancestors has wet the territory. ${ }^{8}$ When the road construction passed the site, the Worowatu ritual leader, 'Ameka'e Muwa, had to perform a special ritual with chicken blood to wet the stone and ask permission from the ancestral spirits who dwell there.

The following two examples of rituals also illustrate the notion of Worowatu sacred geography. The first has to do with 'extending the boundaries of someone's land' ( $p$ i singi rete ra' $i$ ). It is considered a criminal action to thus annex another's property; as well as a negation of, or false claim to parenthood. In order to settle a subsequent boundary dispute, a ritual specialist ('ata madi) recites an oath, witnessed by both parties:

\section{Ke ko'o pata kita peka mena}

Our words have reached the eastern end 
2. Ko'o seru kita rembu rade

3. Ngara poa né'e wengi rua

4. Sai ta pi singi rete ra'i

5. Tau bhora ko'o pata seru 'ine 'embu

6. Ta negha wedu

7. Mo'o dako kiki tuka

8. Mo'o manu kale 'ate 'imu.

9. Mota kau bhida koja

10. Membu kau bhida ra'u

11. Mota pu'u ridi dolo jeka réde dudu

12. Mata kau pi rua

13. Re'e kau tenda tedu
Our conversation has reached the western end

If it happens in the future

Someone wants to extend his boundaries

Someone brings down the words of the ancestors

Who have decided

The dog will bite his belly

And the chicken will peck his liver

You will be exterminated like a canary

You will become extinct like ara'u tree

Your extermination starts from the corner (near the hearth) up to the back of the house

Your death will be in two (generations)

Your misfortune will be in three generations.

After the oath has been recited, both parties eat the livers of a chicken and a dog while drinking toddy. A false claim to landownership can result in deaths, famine, drought, earthquake and disharmony in the family and society, because the 'mother land' ('ine tana) does not stand firm but 'becomes shaky'. That is also why a pala ritual should be undertaken in the village with the slaughtering of buffaloes at certain times, so the meat will be shared and the blood wet the earth, 'so that the soil does not shake and the stones do not tremble'.

A second ritual concerns theft. If community leaders cannot identify the thief, an oath of eating soil is undertaken to invite the spirit of 'mother land' to be present and to witness. To prove that someone has not stolen something, the suspect has to eat a certain amount of soil, witnessed by the community and a ritual leader. The accused must also recite a particular oath: ${ }^{9}$

1. Ngara ja'o naka tu'u mbée mbée

2. O ngara ja'o pi singi rete ra'i

3. Tana mo'o ka ja'o

4. Watu mo'o pesa ja'o

5. Ngara mona, ja'o mona apa-apa
If I have really stolen or annexed someone's land the land will swallow me the stone will eat me If not, I will be all right 
The religious appreciation of the land's motherhood in eastern Keo society is distinct from Western or modern Indonesian ideas of land as a privately owned commodity. The 'Udi-Worowatu people believe that their 'ownership' of land is intrinsically linked to their mythological knowledge of the ancestors' places of origin and paths of migration. The paths that have been travelled by their ancestors, for instance, from So'a through Ma'umbawa and Ma'undai or from Paulundu through Ngera, or from Sumbawa through 'Eko Kota and Paga, seem to provide a map of identity. Keo people understand their country and link themselves with specific places. The travels of the ancestral beings, and the power they left at specific locations, bind together those people who claim to be their descendants. This linking of place with mythology in a sacred topogeny provides an important key to understanding why rituals to do with the land are so fundamental to the stability of Keo society.

An incident involving the destruction of a sacrificial post (léto laka) in the village of Witu in 1937 provides a pertinent example. A whole generation from Witu had neglected their past and their topogeny, which resulted in continuing conflict and violence. Another conflict in 1962, between the villages of Ma'uara and Bedo, was also caused by a denial of the past. At that time, the village of Bedo was transferring its cultural monuments from 'old Bedo' to 'new Bedo', a village now known as Kodinggi. The people of Ma' uara, who used to be members of a traditional alliance, Bedo-Dokarea, refused to be involved in the ritual. They claimed that their ancestor, Tai, was older than Bedo's ancestor, Seso. That is why they further claimed that the whole ritual should belong to 'Embu Tai ('oda tau ko'o 'Embu Tai). The subsequent dispute over ritual precedence required police involvement to calm down the two parties.

Certification of land is still very rare among the eastern Keo people, and the so called 'Seri A Letters' issued by the Indonesian Government nowadays seem to show an appreciation of the past links between ancestors, land and mythology. A 'Seri A Letter' indicates that the clan lands belong to a named ancestor or an'embu, and acknowledges the existence of collective land-ownership of clan land among the 'embu's descendants. The descendants are believed to be the children of the land ('ana tana) and can obtain access to their ancestral land by performing rituals and fulfilling various social-political and religious obligations related to their 'large house' (sa'o mere) or 'source house' (sa'o pu'u) and to their village life (nua'oda).

\section{Guardians of the Land}

At the domain and village level, we can identify at least three different levels of authority dealing with the organisation of Land cultivation and land rights; the Lord of the Land ('inetana 'amawatu), the Overseers of the Land ('ine ku, 'ame lema) and individual cultivators (nio tiko éu tako). The honorific title 'Lord of the Land', and other titles like it, are common in traditional eastern Indonesian 
societies. Arndt briefly describes the role of clan leader (kepala woe) among the Ngada tribe in dealing with clan land. Although clan land is divided between smaller groups, it still belongs to the clan (woe) and its cultivation is never free from the intervention of the clan leader (Arndt 1954: 353-4). Among the Endenese, the central position of therhaki pu'u or the rhaki tana (man of the source/land) is still recognised by other traditional leaders such as rhaki ria bewa or 'speaking lord' and the ndetu 'au or 'village head' (Nakagawa and Aoki 1993: 69; Suchtelen 1921: 69-70, 79, 83). Forth records the honorific title mangu tanangu or 'owner of the land' in Rindi, eastern Sumba. The full title in ritual speech is ina mangu tanangu, ama mangu lukungu, 'mother of the land, father of the river' (Forth 1981: 249). Among the Kedang of Lembata, Barnes also records the existence of the Lord of the Land (leu-auq wala), who possesses the authority to alienate individual fields (etang) because all land in cultivation is the communal possession of the clan (Barnes 1974: 90).

In 'Udi-Worowatu, which is typical of Keo and even of Nage, the full title for a Lord of the Land is 'ine tana 'ame watu, 'mother land, father stone', and refers to someone who represents a group descended from a common male ancestor or'embu. A Lord of the Land had significant power in organising land tenure and in settling various land disputes, and he even had the authority to take away a man's fields and excommunicate him from village life if he did not fulfil his social obligations. For example, while there was initially land available for so-called war migrants and 'invited warriors' (topo todo dée taka todo nga), he had the right to prevent any individual from cultivating certain pieces of land. Once, in 1937, the Lord of the Land of Worowatu even abolished the right of the Witu people to erect a sacrificial post (léto laka) and undertake apala ritual in their own village of Witu. Nowadays, however, the authority of the 'ine tana 'ame watu seems to be rather nominal. He has no final power of decision in land disputes, but still possesses a moral authority that is binding in the context of adat assemblies.

In the domain of 'Udi-Worowatu, there are lesser village leaders under the Lord of the Land who are called the 'heads of the fields' ('ine ku 'ame lema). ${ }^{10}$ In actuality, these men are leaders or overseers of the ancestral land of specific kin groups or extended families. They are also sometimes referred to as 'village leaders' (mosa nua daki 'oda). ${ }^{11}$ Indeed, every named village has its own leader, who will support the Lord of the Land by taking on some of his responsibilities, or by 'passing on warnings and instructions to the members of his kin group or extended family' (wuku 'udu 'énga 'éko). Usually, this position is held by a lineal descendant of the apical male ancestor ('embu). For Worowatu village, the 'ine tana 'ame watu also functions as the 'ine ku 'ame lema (always chosen from the descendants of Taku Nuru, the joint-office was most recently held by 'Ameka'e Wea, a descendant of 'Embu Waja 'Ake). For the village of 'Udi, this position is filled by the descendant of 'Embu Rangga 'Ame 'Ari; for the village of Bedo or 
Kodinggi by the descendant of 'Embu Je Lendo; while in the village of Tudi Wado the position is filled by the descendants of 'Embu Sambu Mite. ${ }^{12}$ The village leader of Ma'undai, a Muslim village, does not hold the title'ine ku 'ame lema because he belongs to a group of 'invited warriors' (keu mere kambe dewa).

Individual fields cultivated by a personal cultivator are termed nio tiko éu tako. Boundaries are generally demarcated by a line of coconut or areca palm trees. Since no one actually 'owns' the land, a person can obtain rights to the land he cultivates as long as he is actively engaged in exploiting the land, belongs to an indigenous male ancestral lineage and respects various aspects of village life (ndi'i nua mera oda). Aspects of village life that should be respected include the rights of other members to gain access to ancestral land, and the obligation to give contributions of food and animals during the ritual ceremonies held in the village (pebhu tindu ndou mapi).

Each individual field of ancestral land (tana 'ine 'embu) is under the supervision of an overseer of the land ('ine ku ame lema). The individual rights to the cultivated fields can never amount to full ownership or possession but only to a right of cultivating the land for one's livelihood and for feeding one's children (tau tuka pagha 'ana). This idea might be reminiscent of a concept of usufruct, as Hooker suggests:

Van Vollenhoven and later writers, particularly Ter Haar, denied that the rights of an individual could amount to 'ownership' in the European sense by which they meant the availability of the right of a free and unrestricted alienation. Ter Haar indeed went further and refused to distinguish between an individual right of possession and the right of usufruct. (Hooker 1978: 119)

Apart from considering the rights and responsibilities associated with the three levels of guardians of the land, we must also understand the distribution of a sacrificial pig's head in relation to leadership. In 'Udi Worowatu, apart from the Lord of the Land and his Overseers of the Land, other 'elders' (mosa daki) are also considered worthy of receiving special portions at a communal meal (nado mére). ${ }^{13}$ That these leaders must be aware of their responsibilities towards the whole of society is well indicated in the adage; 'The elders should warn after eating and drinking' (mosa ta 'odo ka waka, daki ta'odo minu na' $u$ ), which means that they are responsible for encouraging others to follow the path of virtue in order to obtain harmonious relations within society and with the ancestral spirits. This seems equivalent to the task of mosa laki among the Lio, that is, 'to ensure a reproduction of cosmogonic conditions within the limits imposed by the social conditions in contemporary life' (Howell 1996: 102).

The mosa daki's powers are limited to their own village (nua). Within their village they are known asmosa nua, daki oda. Even the Lord of the Land (ine 
tana ame watu), who also has the title of 'land and stone' leadership (mosa tana daki watu), cannot intervene in any matters of daily governance in other villages (nua). Each nua is a completely independent body in political terms. Hence, when disputes or conflicts arise between the inhabitants or mosa daki of two different villages (nua), then the two parties will meet under the supervision of a mosa daki from a third nua, who is respected and can function as an impartial judge. According to Keo ideology, a judge is the one who acts as a measurer, and who functions by measuring with a device consisting of a long bar and a counterweight which can be moved back and forth along the longer arm of the bar (the person and the device are called tuka timba mata dasi). ${ }^{14}$ In Tana Worowatu, the mosa daki of Nua Bedo (Kodinggi) is called on to act as tuka timba mata dasi whenever Worowatu village is in conflict with either 'Udi or Witu.

A careful examination of ritual speech and practice shows subtle differences in the roles of traditional leaders, and we can identify at least three levels of mosa daki. The highest level is the Lord of the Land, who carries the honorific title 'ine tana 'ame watu. Because he is simultaneously a community leader (mosa daki), he also accepts the title of 'Lord of the Land and stone' (mosa tana daki $w a t u$ ). His moral and political leadership used to extend over a wider territorial space known in the ritual language as mosa gége mére, daki danggo déwa, which literally means 'a big leader who guides in the floods, an influential chief who shepherds in the plain'; that is, someone who has power and authority extending over a wide territory. At the middle level are the Overseers of the Land. Asmosa daki, they receive the honorific title of 'village leaders' (mosa nua daki 'oda or mosa 'udu daki 'éko) or the title of leader of a smaller social unit, such as 'leader of the baskets' (mosa mboda daki wati). A third group are mosa kamba daki wéa. This type of leadership is attained by means of material wealth (kamba wéa: buffaloes and gold) or some form of prestige associated with the outside world. ${ }^{15}$

These categories of leaders, especially the first two, have existed for centuries in'Udi Worowatu society, but colonial intervention also introduced new types of leadership that did not fit the local context. The Dutch Colonial Government introduced the notion of kingdom (radjaschap) under a raja and a number of lower-ranking supporters (kepala mére, kepala nua andMandoor). The Indonesian system of government then introduced another set of leadership positions, such as bupati,kepala camat and kepala desa, with various subordinates such as sekretaris, kepala urusan, kepala rukun tetangga and kepala rukun warga.

Concerning the rights and obligations of traditional leaders, my informant, Severinus Rangga, once explained that they 'put the bad things on their head, and carry the difficulties on their shoulder' (woso su'u ta re'e, wangga ta amba). This statement implies that adat leaders have obligations more than rights. Personally, 'ine tana 'ame watu never receive any material gift from farmers in exchange for receiving land to cultivate. During rituals, however, those land 
cultivators who are immigrant newcomers have to pay contributions in cash and kind, which is referred to as 'adding to and overfilling a half-full basket' (tutu mbotu, penu mbora). These payments are not for the Lord of the Land and the adat leaders as such, but for the whole society.

During communal meals (nado mére), the local leaders alone have the right to 'sit cross-legged' (bhodhu pémba jawa) at the centre of an adat assembly (mbabho ngasi). At the same time, they have obligations to solve problems in the assembly and to instruct the people of the village by way of 'calling the people from the head and the tail of the village' (tau wuku 'udu 'énga 'éko). Only then, during the concluding meal, do they 'receive the head of the pig' (simo 'udu wawi). The social and moral status associated with traditional leadership has nevertheless been sufficiently desirable to create competition among various descent lines for the title of Lord of the Land and other local offices.

In the case of Worowatu, only descendants of the so-called 'three ancestors' ('embu tedu) are candidates for the office of Lord of the Land and are allowed to receive sacrificial animal heads (pig, goat or dog) at communal meals. The gift and subdivision of an animal's head in a village ceremony thus functions as the symbolic representation of a social order of precedence. ${ }^{16}$ The 'three ancestors' are three siblings: Waja De'e, her younger brother, Waja 'Ake, and the youngest brother, Waja Sébho, as depicted in Figure 1. ${ }^{17}$

\section{Figure 1: The founding ancestors of Worowatu and their descendants}

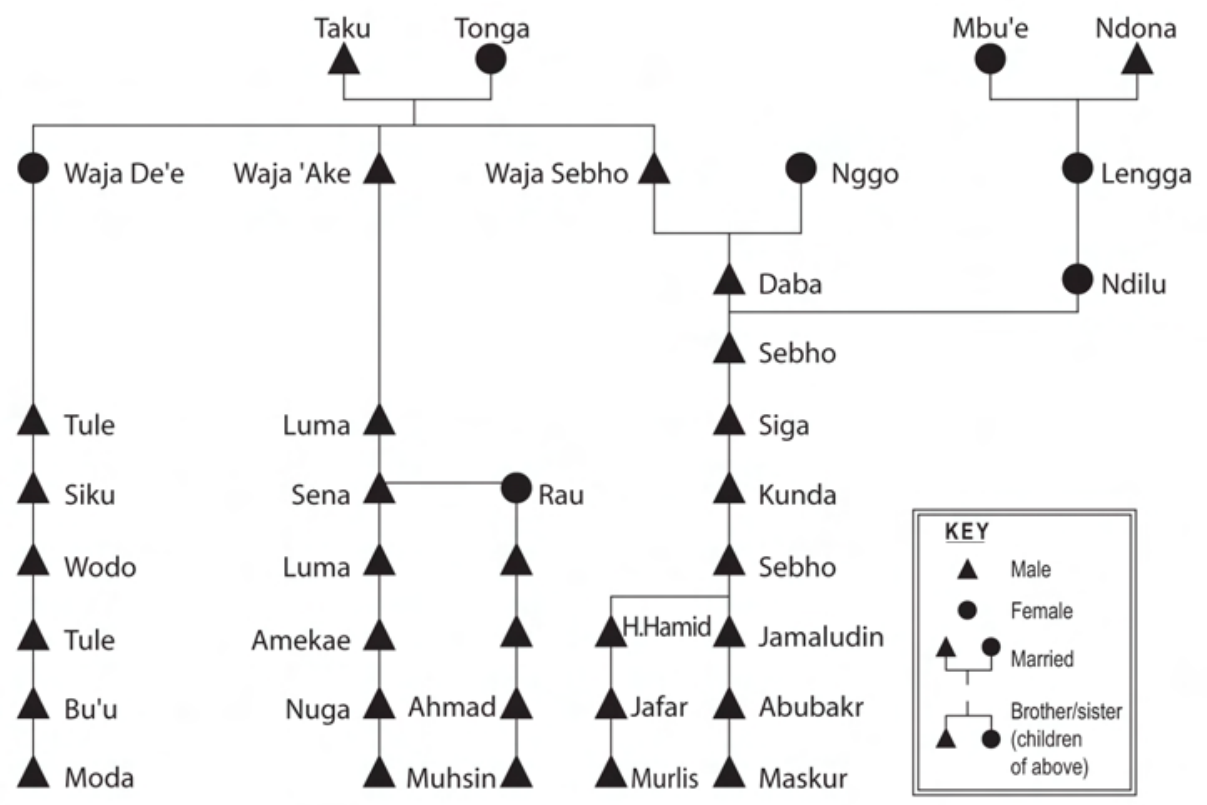


The real authority askepala mére belongs to a descendant of the elder brother, Waja 'Ake, and the man who currently holds this office is Amekae Wea. He is the one who 'sits silently like a basket' (eta kemu, bhodhu jotu bhida ko'o sondu) and never speaks in adat assemblies. The right to speak (mbabho ngasi) falls to a descendant of the youngest brother, Waja Sébho, namely to Jamaludin Husein. My informant explained that the upper part of the pig's head including the ears should be offered to Amekae Wea, who sits, leading and listening, while the snout of the pig should be offered to Jamaludin Husein, because he is the one who speaks. ${ }^{18}$ The eldest female line is not considered in the distribution of power among origin houses. There is a right associated with her seniority as the eldest, namely the right to speak, but this right is passed on to the house of the youngest brother, Waja Sébho. This type of diarchy, or dyadic structure of speech and silence, is encountered in other eastern Indonesian societies as well. ${ }^{19}$

A pig's head is most commonly given to someone as the acknowledgment of his authority and leadership as Lord of the Land or Overseer of the Land. These offices are based on communal acceptance ('ata mbé'o). Consequently, to ask for a pig's head at a communal meal without entitlement is an insult to the whole community and a violation of the social order. For example, an incident related to a pig's head occurred in the early 19th century, which demeaned the Lord of the Land of Worowatu and caused a serious tribal war between 'Udi-Worowatu and the Niondoa and Giriwawo villages. ${ }^{20}$ The oral history is as follows:

Once upon a time, 'Embu Daki Tonggo from Sa'o Mere Doka Ora (central large house) in the village of 'Udi invited the neighbouring village leaders (mosa daki), relatives, friends (minda woe ka'e ari) and people in the village to participate in clearing a garden (songga) in Dandu. The leaders from the neighbouring villages were 'Embu Nanga Medi from Niondoa, 'Embu Jawa Wonga from Giriwawo, 'Embu Siga Dalo from Worowatu and 'Embu Tiko Embo from Bedo. At breakfast time (pesa 'uta poa), Nanga Medi and Jawa Wonga asked for the pig's head, but Daki Tonggo did not give it to them. This degenerated into a dispute. The work did not go well. The leaders from 'Udi, Worowatu and Bedo with their people abandoned their work and left the leaders of Giri Wawo and Niondoa behind. They brought their food down to Ku Dhema, near the village of 'Udi, where they had their communal meal (nado $\mathrm{ka}$ ) on their land. Nanga Medi and Jawa Wonga did not come along. The conflict went on and resulted in a tribal war between the two parties. Tiko 'Embo sided with and helped the 'Udi-Worowatu group. Nanga Medi and Jawa Wonga's group sent a courier to seek help from Tiko 'Embo from Bedo. Unofficially, Tiko 'Embo sent several men under the guard of 'Embu Wenggu Wonga as peacekeepers (koe timbo née tuki 'api). The main support was received from the Lio people ('Ata $A k u$ ) led by 'Embu 'Epu 
Kojo. The 'Udi-Worowatu party sought help from 'Embu Nggawa Ende and Kala Ende. Both parties used guns and black magic (kadha), and the war is said to have lasted for 12 years.

At the end of the war, it was announced that Pi'o Bhoko, a man from 'Udi, and the invited war leader from Lio, Epu Kojo, had both been killed. Finally, a Bedo peacekeeping team was able to bring about a truce. As a reward, Bedo village received seven pieces of land from the Niondoa and Giri Wawo parties.

\section{Incorporated Groups}

The following categorisation of incorporated immigrant groups provides an understanding of the rights of newcomers to cultivate the land on the basis of various traditional contracts. The newcomers are incorporated into or installed inside a local group.

One category of newcomers are 'war migrants' ('ata tama dia, kono ondo). An example are the people of lower Worowatu (Worowatu Wena), who are descendants of people from Ndai ('Ata Ndai) who had left Ndai after being invaded and defeated by the people of Noli. The refugees were protected by the people of Worowatu and made members of the community through a contract, which states that they are 'free to chop with axe and cutlass in clearing the land' (topo todo dée, taka todo nga). From the beginning, however, there was a condition stipulating that 'the daughters you bear will be our son's wives' ('ana ta miu dhadhi, tau fai 'ana kami). Thus the migrant group has been a wife-giving group for the indigenous people of Worowatu, although their social rank is still differentiated from that of other wife-givers to the village. Their contribution to ritual ceremonies is not a 'main contribution' (pebhu tindu) but an 'additional contribution to make up any shortfall' (tutu mbotu penu mbora). ${ }^{21}$

A second incorporated group in Worowatu are the so-called 'supportive neighbours' ('ata ta ndi'i 'ipi mera kemo). ${ }^{22}$ This group includes the descendants of 'Embu Tai from the nua of Witu. According to oral history, 'Embu Tai came to settle in 'Udu Sambi Rupu, on Worowatu territory, without asking permission. He then committed a crime by stealing a goat from the Lord of the Land. 'Embu Waja 'Ake wanted to chase him away but 'Embu Tai promised to be a loyal supporter. In the oral history of Worowatu, the subsequent sharing of land with Tai's descendants has created a ritual confederacy, which implies mutual assistance in working the land, in the installation of cultural monuments and in enacting ritual performances. The newcomers have to ask for the presence of the Lord of the Land at their own major rituals, and are obliged to contribute tutu mbotu penu mbora to Worowatu rituals.

A third group is that of the 'invited warriors' ('ata kéu mére kambe déwa). Belonging to this group are descendants of a number of Muslim pioneers: Nggawa Ende in Ma'undai, and Susu 'Ele Terpase in Ma'unori. ${ }^{23}$ Nggawa Ende (from 
Ende) was invited by 'Embu Siga and 'Embu Sena from Worowatu to join in a tribal war between Daki Tonggo and Jawa Medi. He and his descendants in return received a gift of some land in Ma'undai.

The incorporation of Nggawa Ende, the Hadramis and other migrant groups seems to be similar to the process of 'naturalisation' in modern nations in some ways. It involves an individual or a group giving their voluntary allegiance to a certain local group on the basis of a contract, which specifies the 'primary goods' (Rawls 1971) associated with citizenship. In the Keo context, the outsiders are incorporated and seen as an inner group because of their ancestral service as participators and helpers (to'o jogho mbana daka) in a war.

Such traditional contracts have been challenged by recent social changes in the region. Economic competition has forced the Hadramis to find other locations which are more promising for their businesses. At the same time, population growth has led to land scarcity in Ma'unori, and has caused the indigenous people to reclaim their clan land. These changes have resulted in a conflict over house sites ( $d a^{\prime} e$ sa'o) between the Hadramis and the descendants of 'Embu Mite Pale in Ma'unori.

The structure of precedence concerning traditional leaders and various categories of indigenous and newcomer groups in tana Keo is depicted below in Figure 2.

\section{Figure 2: Structure of precedence in dealing with Keo land cultivation}

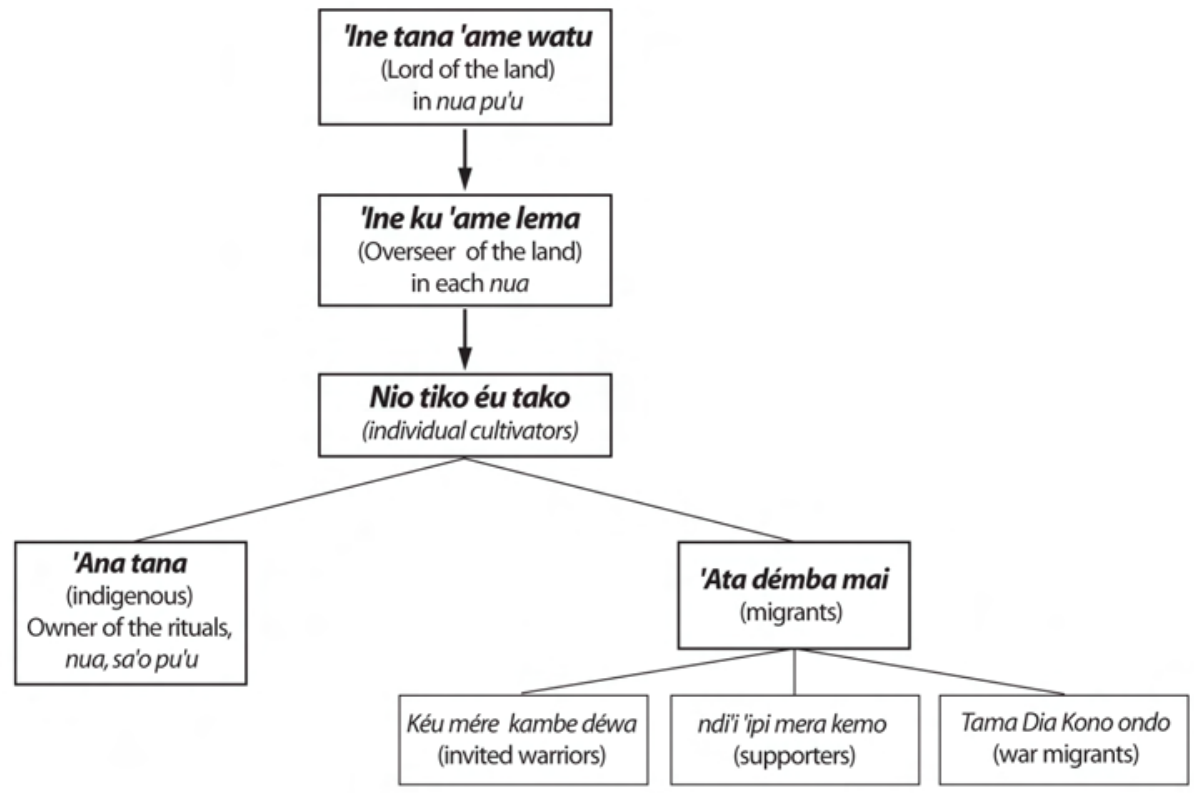


The relationships between local and newcomer groups is not predetermined but is always the outcome of a specific history. Newcomers can gain rights similar to those of earlier settlers, as the following case study will illustrate.

On October 11, 1997, I had an opportunity to speak with Al-Hadat from a Hadramis family in Ma'unori. I was accompanied by Ignas Isa and Severinus Rangga. We discussed various topics including social, religious and cultural problems. The main topic of our discussion was Sayyid Habib Idrus Al-Hadat, who was a pioneer and leader of Islam in Ma'unori. We also discussed why the Hadramis family occupies a piece of land in Ma'unori as their house site.

An oral history shared by various local leaders, including Ignas Isa, states that the occupation of the land by the Hadramis family was based on the involvement of 'Embu Susu Ele Terpase from Ende in a tribal war between the Noli and Ndai tribes. In that war, the exact date of which is not known, the Noli tribe, assisted by Susu Ele Terpase, succeeded in destroying the Ndai tribe by using the fire-gun known asMeriam Se Ndai, brought by Susu Ele Terpase. As a reward for his contribution, he was given a piece of land in Ma'unori for his family to settle on (tau koe nua kadi 'oda). That land later passed to his daughter, No' o Lalo, whose daughter, 'Ine 'Ipa Ende, married Habib Idrus Al-Hadat, whose father, Habib Umar Al-Hadat, was a Hadramis from a city called Terim. ${ }^{24}$ Habib Idrus landed and settled in Ma' unori in 1914 and built the mosque Bait al-Rahman there (see Figure 3). Until now, the imam and khatib in the mosque are mostly from Habib Idrus's family.

The most interesting point that came up in my discussion with Al-Hadat in July 1997 was the historical process of their incorporation into a large house ( $s a^{\prime}$ o mere) in the village of Nuamuri, and how this incorporation agreement was cancelled after a house site dispute. According to adat law, the family members and the descendants of Susu Ele Terpase, by consanguinal and affinal derivations, are eligible to inherit that piece of land. Hadramis are commonly seen as outsiders who have been made insiders (see also Fox 1995).

The Hadramis are regarded as members of the 'large house' of 'Embu Mite Pale in Nuamuri. Their membership in this ritual house was as a reward for Susu Ele's war service (to'o jogho mbana daka), which is described in ritual language as 'a gift which is never taken back' (ti'i mona wiki pati mona dai). It is obligatory for the Hadramis family to provide ritual contributions known in ritual language as 'additional contributions' (tutu mbotu penu mbora) or 'green beans and resin torches' (mbue kaju api ida) to the 'house' of Mite Pale. In return, Hadramis are no longer regarded as foreigners or migrants, but as people who own the right to cultivate and to settle on clan land in Ma'unori. 
Figure 3: The genealogy of the Hadramis in Ma'unori

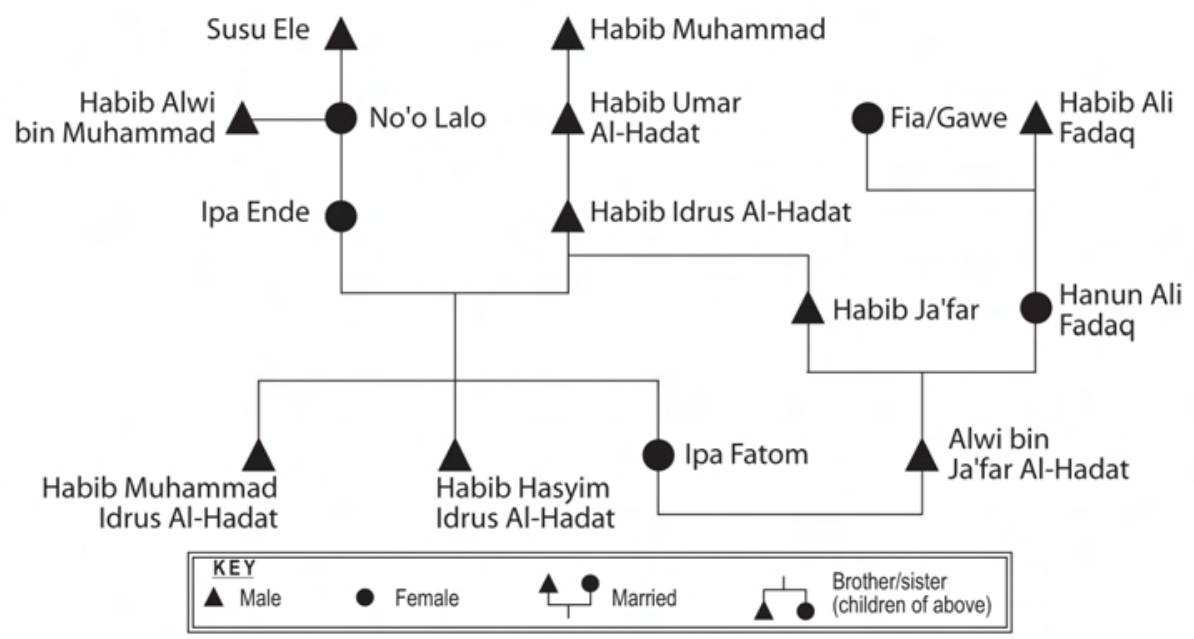

\section{A Conflict Over Land}

Since 1997 the Hadramis family in Ma'unori has been accused by a group in the large house ( $\mathrm{sa}^{\prime} \mathrm{o}$ mére) of Mite Pale of violating the common philosophy of land motherhood by 'certifying' their land claim through the government land registration office. This led to a serious conflict with Gabriel Wundu, an 'Embu Mite Pale descendant. The conflict reached its peak when the government authorities in the subdistrict of Ma'uponggo became involved. The story runs as follows:

After the death of Habib Idrus and his oldest son, Taha Idrus in the 1970s, the Hadramis family left their inherited house site and rented a new house about 20 metres in front of their old house site. The only Hadramis family living in Ma'unori nowadays is Ipa To, one of Habib Idrus's daughters who married Al-Hadat from Waingapu. Other sons and daughters of Habib Idrus live in Surabaya, Ende and Bajawa. Because the house site had been deserted for 20 years, Gabriel Wundu started to build a permanent house on it in 1996, with the involvement of local people and several adat leaders. On January 17, 1997, when one-quarter of the construction was completed, Alwi Jafar Al-Hadat brought the case to the Government at the subdistrict level of Ma' uponggo on behalf of the Hadramis family, reporting that Gabriel Wundu had built a house on their house site, which had been certificated and registered in the National Land Office (Badan Pertanahan Nasional) with a serial number AG 731606 24. 09. 06. 11. 1. 00007, dated March 26, 1997. As proof of their claim, the Hadramis family attached a copy of the land certificate 
with the witness signatures of the village leader (kepala desa), Mbae Nuamuri, and landowners including Gabriel Wundu himself. Eventually an agreement was reached in the subdistrict office (kecamatan) of Ma' uponggo that Gabriel would hand back the land to the Hadramis because the land was 'a gift which is never taken back' ( $t i$ 'i mona wiki pati mona dai). However, as recompense for the construction that had already taken place, the Hadramis family was ready to pay 3,000,000 rupiah. Both parties agreed formally to resolve the conflict in front of a special assembly of traditional leaders from Mbae Nuamuri, which is known in ritual language as 'the head waits for the Endenese, the tail waits for the Javanese or the outsiders' ('udu kére Ende, 'éko napa Jawa). The police from the subdistrict resort of Ma'uponggo, based on this agreement, went to stop Gabriel Wundu continuing his construction. However, Gabriel stirred up trouble again by questioning the validity of the certificate, saying that even though his signature was apparently on it, he had never signed any document for certification of that piece of land. The conflict resumed and was brought to the court in Ma'uponggo, where both parties were urged to find a peaceful and amicable solution (secara kekeluargaan dan damai) under the auspices of the local leaders and legal traditions (hukum adat). After they came back from Ma'uponggo, neither party put the agreement to put the problem before the adat assembly into practice. Gabriel Wundu spread the news that he had been pushed to accept such an option to solve the conflict by the subdistrict government and the Hadramis family. Gabriel Wundu and his family then took the case to court at the district level in Bajawa.

Before the juridical court hearing in Bajawa took place, I visited the District Head, Dr. John Samping Aoh, and discussed the case with him. In our conversation, two important issues were raised in relation to the conflict over the housesite $\left(d a^{\prime} e s a^{\prime}\right)$ ): first, the act of certifying the clan land by the Hadramis family in Ma'unori and, second, the usefulness of traditional principles such as ti'i mona wiki pati mona dai ('a gift that is never taken back'). However, when I revisited the field site in Ma'unori in July 1999 and spent time with Gabriel and his sons, they showed me a bundle of documents in relation to the house site dispute written by both parties for the court in Bajawa. Both parties supplied the court with information on the basis in adat law of their respective claims to possession of the land. The parties created conflicting versions of their ancestral history and of the events that brought the great cannon (named Meriam Se Ndai) into the large house ( $\mathrm{sa}^{\prime} \mathrm{o}$ mere) of 'Embu Mite Pale. 'Embu Mite Pale's descendants (including Gabriel Wundu) contested the claim that a traditional installation had taken place, and explained the presence of the cannon in their house as a reward given by Susu Ele Terpase for the participation of the grandfathers of Mite Pale and Dhae Pale ('Embu Jona and Ndoa) in a tribal war 
in Ende. Apart from the cannon, Susu Ele also gave a piece of land of about four and a half hectares, known as Tanah Sabadeo Tana Kéo, near Ndao, in the town of Ende. According to this party's version, the occupation of the disputed house site by the Hadramis family started with No'o Lalo (Susu Ele Terpase's daughter) and her daughter, Ine Ipa Ende, in the 1920s, after getting permission from 'Embu Isak Ado, Mite Pale's son. Then, Habib Idrus married Ine Ipa Ende and settled there too. Later in 1938, Habib Idrus brought his second wife, Ine Ipa Pulo, from Pulau Ende to Ma'unori.

The Hadramis have their own version of their settlement on the disputed house site, as stated earlier. They claim that the house site was a reward for Susu Ele Terpase for his participation in the tribal war between Noli and Ndai. The land was then inherited by No'o Lalo and her daughter, Ine Ipa Ende, and her husband, Habib Idrus, then by Thaha Idrus and his family until they recently obtained the certification.

From my observation, the adat assembly had not been sufficiently consulted in this dispute. The court in Bajawa, which might have been able to mediate between the two parties, did not listen to the testimony of the traditional leaders of Mbae Nuamuri ('udu kére Ende, 'éko napa Jawa). The Hadramis had violated the philosophy that 'no one owns clan land' by obtaining government certification. In daily practice, such a principle is applied strictly to the clan lands that are cultivated as the source of people's livelihood. For clan lands categorised as house sites and settlements ( $d a^{\prime} e$ sa'o and nua 'oda), such a certification is necessary due to the requirements of national civil laws and regulations. Anyone who wants a permit to construct a permanent construction (Surat Ijin Mendirikan Bangunan) must first provide a land certificate. However, the certification by the Hadramis had not been carried out with the permission of the adat assembly.

In a conversation with Gabriel Wundu during my return to the field on July 29, 1999, he explained that the Hadramis (c.q. Al-Hadat) had violated the traditional contract between 'Embu Mite Pale and 'Embu No'o Lalo, Susu Ele Terpase's daughter. He claimed that the legal status of the disputed house site was captured by the following traditional saying:

1. Kami ti'i mona ka wiki

2. Kami pati mona ka dai

3. Asa miu to'o ma'e ndi'i

4. Mbangga ma'e mera

5. Miu pana ma'e todo dangga

6. Poke ma'e todo ndore
We give and never take back, we share and never recollect, but you have to wake up without staying, you get up without restraint, you send an arrow, never passing the limit, you throw never passing the border, 
7. Miu wiwi ma'e isi

8. Dema ma'e de'e

9. Ngara to'o ndi'i mbangga mera

10. Ko'o kami, wado 'ena kami

11. Ngara miu pana todo dangga

12. Poke todo ndore

13. Ne'e wiwi isi dema de'e

14. So'o ria miu lela your lips (words) must never overact, your tongues never be sharp.

If you get up with restraint, ours will be ours.

If you send an arrow passing the limit,

if you throw a stone passing the border,

if your words overact and are sharp, it would be better for you to go.

In Gabriel Wundu's view, this Hadramis family had overacted in their words and behaviour by certifying the house site and claiming that it was their personal inheritance from their grandmother, No'o Lalo, which had been owned for 100 years and passed on for generations before it was certified on March 26, 1997.

In dealing with this issue, the District Head, Ngadha, seemed to adopt a different view from the court. In a personal conversation with me, he explained that the Indonesian national civil law still recognises the values of adat law. In his opinion, the agreement that was contracted by the ancestors was characterised by the principle of ti'i mona wiki pati mona dai and such traditional principles are a valuable inheritance to be passed down to the next generation. A one-sided negation of the agreement and its principles is really a violation of the adat law, and therefore should be solved by the local adat assembly. That is why the District Head thought the ideal solution for the conflict between the Hadramis family in Ma'unori and 'Embu Mite Pale's people in Nuamuri would be to return the case to the adat assembly of the village of Nuamuri.

On April 28, 1999 the court made a temporary decision that the Hadramis' claim to the land was dismissed (niet onvankelijk verklaard). Gabriel Wundu interpreted the decision as a victory. The Hadramis, however, saw hope therein for a further case if they could provide new evidence. In the meantime, the Hadramis family decided to leave Ma'unori and move to Ende. This move amounted to a cancellation of the longstanding adat contract of their incorporation as newcomer settlers, and resulted in this Muslim Arab family having to abandon their ancestral tomb located in the backyard of the Bait al-Rahmat Mosque in Ma'unori, which is another matter for concern.

\section{Oral History and Land Tenure}

Why is it that there are two versions of oral history about the great gun or cannon, Meriam Se Ndai? From a literary point of view, there are two reasons that should be taken into account to understand why Mite Pale's descendants deconstructed and reconstructed their version, which is different from the 
version of the Arab's family and the whole society of 'udu kére Ende 'éko napa Jawa. The first reason is the gradual erosion of oral culture by written tradition in Flores. In the everyday discourse of a non-literate people such as the Keo, the storytellers are not merely entertainers and literary artists. They are at once scholars, jurists and custodians of the traditions of their society in the original sense (Sweeney 1991: 22-3). When written traditions were introduced, the new repositories of traditional knowledge were educated storytellers and writers who could more effectively store, retrieve, transmit and sometimes reconstruct the traditions of their people. The dependence on the memory and oral recitation skills of adat leaders was no longer absolute. Eventually, a whole set of new criteria was used as a legal basis in modern disputes: 1) land certificates, 2) evidence of who holds the sacred paraphernalia in dispute, and 3) logical and historical relationships between any group and the disputed object. This seems to be the start of an erosion of the traditions of oral history (Sweeney 1987: 284).

The second reason for there being two versions of this history concerns the relationship of the text to issues of power and knowledge. In modern literature, a text is viewed commonly as a written communication enmeshed in a context and environment-historical, cultural, political and religious. Although the father of structuralism, Lévi-Strauss, studied mainly unwritten texts or oral traditions, most of the structuralists perceive the text rather as a series of forms produced by the institution of literature and the discursive codes of a culture. However, the postmodernists argue that every text is related to every other text, and this makes for 'intertextuality' (Foucault 1972; Kristeva 1980: 36) and emphasises the relationship of the text to power and to the many forces that influence its production and its final form (Rosenau 1992: 36). The reinvention of the story about Meriam Se Ndai by Mite Pale's descendants should be viewed in line with Foucault's theory.

The abuse of power by the Government-appointed village head (kepala desa) of Mbae Nuamuri was one basic reason why Mite Pale's descendants created a new version of the story. The village head seemed to have acted in collusion with the subdistrict leader (camat) and the Hadramis in recommending to the BPN (Badan Pertanahan Nasional) that it should issue a certificate for the disputed house site. At the same time, the power of the adat assembly seems to have declined and was therefore not taken into account by either the kepala desa or thecamat. Decisions made by functionaries of President Suharto's New Order State (Orde Baru) were challenged retrospectively by 'Embu Mite Pale's descendants, as is evident in the following letter, which they sent to the Juridical Court of Bajawa:

It is clear that the certification on behalf of Thaha Idrus (an Arab) is false because it has been issued by the New Order Government in a manner categorised as an act of corruption, collusion and nepotism. The New 
Order Government pretended to issue mass certification on the basis of a program known as the National Project of land certification (PRONA) for the government's benefit as well as the people involved in it. This [mass land certification scam] should be taken into consideration in this court-case (in the current Reformation Era) in order that [the court decision] should not be accepted as valid, and [the defendants] should not be tried as criminals. (Tangkisan serta Eksepsi, February 17, 1999, p. 17) 25

\section{Conclusion}

On the basis of oral tradition and mythical history, I would conclude that under the Dutch, the size of a landholding might have played an important role in political leadership in some parts of eastern Flores. The people of 'Udi-Worowatu, however, based their Lord of the Land position on the authority passed down from generation to generation from the founding ancestor, Taku Nuru. Although this traditional office was more pertinent to the ritual sphere than to modern politics, recent democratic elections have given descendants of the Lord of the Land a new opportunity to gain political office by using their traditional prestige, their newly acquired educational qualifications and a knack for charismatic leadership.

The people of 'Udi-Worowatu clearly still hold to the philosophy that 'no one owns the land, but people belong to the land'. This philosophy depicts a notion of the land as mother, as is implied in the metaphors of ritual speech. Every individual cultivator (nio tiko eu tako) has a right to a share of ancestral land (tana suku ortana 'ine 'embu) under the supervision of the guardians of the land, namely the Lord of the Land ('ine tana 'ame watu) and the Overseers of the Land ('ine $\mathrm{ku}$ 'ame lema). In proportion to their land usage rights, they have socio-religious obligations to participate in various rites dealing with the sacred land that is under the control of the ritual domain (tana) of Worowatu, a federation that consists of the villages of Witu and Ma'uara. Groups of Muslims and indigenous migrants have been incorporated into a particular source house, and are all part of this ritual confederacy.

Every village (nua) in the domain (tana) of Worowatu consists of a constellation of dwelling houses ( $\mathrm{sa}^{\prime} \mathrm{o}$ ndi'i) derived from a single source house (sa'o $\left.p u^{\prime} u\right)$. Each village has its own elders ('ine $k u$, 'ame lema) and can be categorised as a unit of customary law ('uku'ada), underwritten by a very strong link of kinship and co-residence. In reality, this extended kin group has the right to cultivate and control certain pieces of land through the office of the 'ine tana 'ame watu. Moreover, the daily cultivation of the land is carried out by particular individuals or families. Continuous cultivation of a certain piece of land or even several pieces of land tends not to create or produce personal rights over the land. In dealing with the rights and authority of 'ine ku, 'ame lema, 
some of the sociopolitical and religious authority given to the Lord of the Land is also invested in the sub-lords of the land, who operate at the level of the nua. The authority to receive a pig's head, to lead an adat assembly (mbabho ngasi) as a legal and executive leader, and to place the first corner stone for a new construction are all invested in the 'ine ku, 'ame lema.

Although narratives of origin are designed to establish an order of precedence for each person or house group, conflicts over power and status are continually played out in disputes between neighbouring groups, between the descendants of the younger brother and the elder brother, between the Lord and the Overseers of the Land. The most controversial case of conflict recorded was between the indigenous people and Muslim migrants, the Hadramis, in Ma'unori. The Hadramis were outsiders but had been accepted as insiders for generations until their recent violation of theadat contract with the indigenous people caused tension. Thus, the notion of installing outsiders on the inside has not proven to be an absolute transformation in this case. The relative ease of contestation for land claims based on oral history may well provide a basis for future conflict between indigenous people and migrants, between the commoners and the Lord of the Land. In the context of current national politics, religion is becoming more important as compared with other forms of identity construction. However, the idea that the indigenous people are 'children of the land' ('ana tana) remains central, as does the idea of indigenous groups entering relationships with newcomers by incorporation into a common source house and by subsequent sharing of the same ancestral land (tana 'ine 'embu).

\section{References}

Arndt, Paul. 1954. Gesellschaftliche Verhältnisse der Ngadha. Freiburg: Studia Instituti Anthropos, No. 8.

Barnes, Robert H.Kedang: A Study of the Collective Thought of an Eastern Indonesian People. Oxford: Clarendon Press.

BPS Ngada. 1995. Ngada Dalam Angka 1995. Bajawa: Central Bureau of Statistics.

Clarence-Smith, W.G. 2001. 'From horse trading to commercial supremacy: Arabs in the Lesser Sunda Islands, c1800 to 1940.' Unpublished paper.

Forth, Gregory. 1981.Rindi: An Ethnographic Study of a Traditional Domain in Eastern Sumba. The Hague: Martinus Nijhoff.

Forth, Gregory. 1998. Beneath the Volcano: Religion, Cosmology and Spirit Classifications Among the Nage of Eastern Indonesia. Leiden: KITLV Press.

Forth, Gregory. 1994a. 'Keo Kin terms.' Anthropos, 89. pp.95-109.

Forth, Gregory. 1994b. 'Consideration of Keo as an Ethnographic Category.' Oceania, 64 (4). pp. 302-15. 
Foucault, Michel. 1972.Histoire de la Folie. Paris: Gallimard.

Fox, James J. 1977. Harvest of the Palm. Cambridge (Mass.): Harvard University Press.

Fox, James J. 1995.Installing the Outsider Inside: The Exploration of an Epistemic Austronesian Cultural Theme and its Social Significance. Leiden: Leiden University.

Hooker, M.B. 1978. Adat Law in Modern Indonesia. Kuala Lumpur: Oxford University Press.

Howell, Signe. 1996. 'A Life for Life: Blood and Other Life-Promoting Substances in Northern Lio Moral Discourse.' In S. Howell (ed.), For the Sake of our Future: Sacrifice in Eastern Indonesia, Leiden: Research School CNWS. pp. 92-109.

Kristeva, J. 1980.Desire in Language. Oxford: Basil Blackwell.

Langan 1921. 'Endeh (Flores).' Mededeelingen van Het Bureau Voor De Bestuurszaken der Buitengewesten, Bewerkt Door Het Encyclopaedisch Bureau,No 26.

Sweeney, A. 1987. A Full Hearing. California: University of California Press.

Sweeney, A. 1991. 'Literacy and the Epic in the Malay World.' In J.B. Fueckiger and L.J. Sears (eds), Boundaries of the Text, Michigan: Universtity of Michigan Press.

Therik, Tom G. 1995. 'Wehali: The Four Corner Land: The Cosmology and Traditions of a Timorese Ritual Centre.' Unpublished PhD thesis, The Australian National University, Canberra.

Tule, Philipus. 2001. 'Longing for the house of God, Dwelling in the house of the Ancestors: Local Belief, Christianity and Islam Among the Keo of Central Flores.' PhD thesis, The Australian National University, Canberra.

\section{ENDNOTES}

1 This paper is based on the author's ANU PhD thesis (Tule 2001), which was published in 2004. Note that the term'embu refers to male ancestors.

2 Forth has explored some of the various meanings of the term 'Keo' (1994). I prefer to understand Keo as the name of a territory that was merged with the Nage region by the Dutch (1923). The name Keo may have originated from a village named Keo Belo, or Nua Keo, near Maukeo and Mauponggo. Keo came to be used as a designation for the whole domain, comprising 10 subdistricts, unified into Kerajaan Kota Keo under Muwa Tonga. The 10 secondary districts were Tonggo, Riti, Lewa, Wajo, Wuji, Pau Tola, Kota, Sawu, Lejo and Worowatu (Forth 1994b: 309-10).

3 Note, however, that Séme Rau was not born in Worowatu village. He was a 'returning child' ('ana mera) from the village of Witu. The term 'ana mera is commonly translated into Indonesian as 'adopted children' (anak angkat), but this translation does not capture its exact meaning among the Keo. A better translation would be 'incorporated children' or 'returning children'. The implication is the incorporation of a person back into his/her mother's natal group or source-house. Filiation, or quasi-filiation by nurturing, is the main criterion. Such incorporation provides access to inherited leadership positions in a source house and its territory, and the right to claim land even if one is not a resident (Langness 1964: 170). 
${ }^{4}$ Leto laka is related to the destruction of the sacrificial post (laka) in the village of Witu in 1937 because the people of Witu did not wait for the presence of the Lord of the Land of Worowatu.

5 Jamaludin explained that the tree is also believed to be the source of richness and prosperity (bhanda ngawu). The people of Worowatu are unlucky because it fell down with its tip seaward. This meant that the people from overseas ('ata tana dau), the outsiders or 'people of Java' ('ata Jawa), would always be rich while the people of 'Udi-Worowatu are poor. According to local interpretation, the tip should have fallen uphill (pointing towards the 'head' of the mountain) and the trunk or roots downhill (towards the 'tail' or 'feet' of the mountain).

6 A recent political movement (1997) wants to split the sub-district of Ma'uponggo into East and West Ma'uponggo. The new East Ma'uponggo subdistrict is to have its headquarters in Ma'undai, on about 4.5 hectares of land donated by several land cultivators from Worowatu, Bedo and Ma'uara villages. Although this movement could lessen the previous conflict between both parties (Worowatu and Ma'uara), those land-cultivators who are from Ma'uara have not yet expressed their agreement.

7 Tuka literally means belly or stomach. The people of 'Udi-Worowatu are limited in their knowledge of anatomy and the physiology of pregnancy, however, and hence they equate the womb and stomach.

a Wundu is a local variety of fishing line made from hand-spun cotton. Puru wundu mbudu wutu negha mona dhu means to extend 40 times 40 arm-lengths of cotton fishing line into the deep sea; and still it cannot reach the furthest reach of the border of their marine territory.

8 A story tells that Daba Nggo (a leading figure from Worowatu) and Juju 'Ari were both murdered in Nua Ora by Rangga 'Ame 'Ari when they were found committing adultery.

9 In Keo language, this sort of oath is called Supa Ka 'Awu (soil-eating oath).

${ }^{10} \mathrm{Ku}$ means a small piece of land cultivated by an individual or family, a plot, or a parcel of land.Lema is synonymous with $\mathrm{ku}$. The term lema rarely stands alone, nearly always occurring together with $k u$.

11 This level of leadership is equivalent to thetulaku paraingu of Rindi (Forth 1981: 257).

12 The recent village leader of 'Udi Worowatu (Kepala Desa 1998) is Mathias Ndiwa, one of 'Embu Sambu Mite's descendants.

13 Mosa daki literally means 'mature male'. Mosa also means 'mature' in reference to male dogs, buffaloes, horses or cattle, but not other animals. Daki means 'male'. It seems to be a synonym of aki in Keo and a metathesis oflaki in Indonesian and Malay.Daki is also used in describing a man as monogamous (ha daki) or bigamous (daki rua) or polygamous (daki rua tedu ordaki séwe).

14 Among the people of Mbae Nuamuri village, another terminology is used for this adat judge: 'the leader who has a stick which is not sharp, but has a long cloth to cover' (mosa bubu nusu, débha duka déwa). The office is vested in the sub-clan Sina Jai.

15 This newer type of leadership has come to dominate the others to some extent. Belonging to this group are successful traders and others with material wealth, such as 'buffaloes and gold'. Another local term is 'people who are rich' ('ata ta bhanda ngawu). Recently, even the Catholic priests, retired government officials and teachers are included in this type of leadership.

16 Instead of the head, in other parts of Flores they offer the tail and the back or the foot.

17 There is a new version that claims that the three founding ancestors who received the title 'waja' (honourable) were not real siblings. One informant claimed that 'Embu Sena 'Ea was a classificatory brother ( $k a^{\prime}$ e ari sa'o tenda) from Mbeku, a village four kilometres further north. Because 'Embu Waja 'Ake lacked house members (weki weni do todo), Sena 'Ea was adopted to be a house chief instead of 'Embu Bajo Dhéma, a migrant worker (tae mbene) from Bajawa. Another source mentions that 'Embu Waja Sébho was originally a ka'e ari sa'o tenda from the village of Jawa Wawo. He was incorporated into and inherited from the female house of Waja De'e. Through an adat process, 'Embu Waja De'e gave her authority back to her brother, Waja 'Ake, and then he handed over to Waja Sébho, because Waja De'e was only a female (kote one). Through that process, Waja Sébho was elevated to the status of a real sibling ( $k a^{\prime} e^{\prime}$ ari) and given authority to be a 'spokesman' (dipi wiwi déu dema). Thus the status of lord of the land ('ine tana 'ame watu) should really go to the descendants of Waja 'Ake.

18 Because Jamaludin Husein is a Muslim, the pig's snout will be taken by his delegate. If a goat is slaughtered, he will receive the goat's nose himself.

19 Such a dyadic structure is encountered in Wehali, where the male Liurai is authorised by the female Liurai, known asmaromak oan, to do the speaking. Themaromak oan remains silent in the ritual centre (Therik 1995: 81, 101). In the case of Daja village, the three founding ancestors ('embu tedu) still retain the female as eldest because she is considered wise and an eloquent speaker. 
20 Based on the reconstruction of life stories and genealogies of several local leaders (mosa daki), it is estimated that the war began about 1813 and ended in 1825 .

21 In Ma'unori and Nuamuri, the same type of contribution is known as 'green bean and resin torch' (mbue kaju 'api 'ida).

22 Ndi'i 'ipi mera kemo literally means 'those who live close to someone's hip'.

23 My informant in Ma'unori mentioned that before the Noli and Ndai war, Mite Pale was invited by Susu 'Ele Terpase to Ende to help in the war between Mbonga Wani and Ndao. The people of Mbonga Wani under the leadership of Susu 'Ele won the war and were given a piece of land in Ende known as tana saba déo tana Kéo.

24 Habib Umar Al-Hadat was born in the city of Tarim (Hadramaut) and migrated to Kupang in the 1850s. Another Hadrami in Sumba (Waingapu), Habib Ali Fadaq, was also a migrant from Medina. He married a girl from Ende, Fia Gawe, a relative of Susu 'Ele. Habib Idrus Al-Hadat, who was born in Kupang (1880s), migrated to Ma'unori in 1913 and died in Ma'unori on April 16, 1951 (see Plate 3.2). Habib Muhammad Idrus Al-Hadat was born in Ma' unori, where he became the imam of the local mosque until the 1970s. He moved to Kupang where he died in 1994 and was buried near the tomb of Sayyid Abd al-Rahman bin Abu Bakr al-Qadri, who used to live on Sumba. Related to the Hadrami sultan of Pontianak in West Borneo, the Sayyid was exiled from his native city in 1829, for reasons that remain unclear. He built up a friendship with a Dutch official in Batavia, D.J. van den Dungen Gronovius, and went to Kupang when Gronovius was appointed Resident there in 1838. After working for the Dutch customs authorities for a while, Sayyid 'Abd al-Rahman went as Gronovius's commercial and political agent to Ende (Flores), where he married a daughter of the Muslim sultan. Gronovius lent Sayyid 'Abd al-Rahman 14,000 Dutch florins and gave him permission to settle in 1842 on Sumba, where he became the leading horse trader until his death in 1878. His horse-trading business expanded so rapidly and extensively that it radically affected the political economy of the island. By 1879, the main traders in Sumba consisted of 13 Arabs and three indigenous Indonesians (Clarence-Smith 2001: 6; Forth 1981: 8; Fox 1977: 163; Parimartha 1995: 174-6).

25 In the Indonesian original the text runs as follows: 'Jelaslah, bahwa sertifikat atas nama Thaha Idrus [an Arab] itu adalah palsu, karena dibuat dengan cara yang tergolong perbuatan KKN (Korupsi, Kolusi dan Nepotisme) dimana Orde Baru dengan berdalihkan Proyek Nasional (Prona) Penyertifikatan Tanah secara masal demi keuntungan pribadi pula dari pihak pembuatnya, sehingga perlu mendapat perhatian utama dalam perkara ini (di Era Reformasi) untuk tidak dibenarkan, ataupun dipidanakan' (Tangkisan serta Eksepsi, 17 Februari 1999, hal. 17). 